\title{
PESAN DAKWAH HASAN AL-BANNA DALAM BUKU MAJMUA'AT AL-RASAIL
}

\author{
Muhamad Hanif Fuadi \\ Sekolah Tinggi Ilmu Tarbiyah At-Taqwa KPAD Bandung \\ fuadi9070@gmail.com
}

\begin{abstract}
This article analyzes the message of Hasan Al-Banna preaching in the book Majmu'at al-Rasail relating to the aqeedah, sharia, and morals, The study uses critical discourse analysis method of Norman Fairclough with an emphasis on the background of sosial situation until the massage of da'wah was formulated. The result of the reaserch show that the massage of $d a^{\prime}$ wah in the book Majmu'at al-Rasail can be explained, among other: the massage of the faith in theological discourse, the massage of sharia in the discourse of power and the moral massage in the discourse of social relations. The monotheistic belief system must be able to provide the divine spirit in all dimensions of life. The spirit grow out of true, pure, clean faith from the element of shirk to God; the sharia system requires applicable law according to the teaching of Islam, focusing on a number of social and political problems that it the country of Egypt after the destruction of the Ottoman Caliph wich fell into British hands. The massage of Hasan al-Banna's preaching was oriented toward reforming the living system wich was damaged by colonialism and desirous of returning it to the Islamic system.
\end{abstract}

\section{Keywords: Da'wah Message; Book; Hasan Al-Banna; Critical Discourse Analysis.}




\section{A. Pendahuluan}

Perkembangan dakwah dapat dilihat dari berbagai aspek dan pendekatan, salah satunya dari pesan dakwah. Dinamika pesan dakwah berkembang ketika ajaran Islam sebagai materi dakwah diolah dan dimodifikasi sesuai dengan kebutuhan praktis dakwah. Pesan dakwah tidak lagi terbatas pada teks Alquran dan Hadis, melainkan sebuah pemahaman maupun penafsiran sebagai buah dari interaksi antara manusia yang hidup dengan pikiran serta pengalaman dengan sumber ajaran Islam. Bahkan pesan dakwah disusun dan dirumuskan sesuai dengan tujuan dakwah. Sebuah pesan mengisyaratkan pola pikir dari pembuat pesan. ${ }^{1}$

Ditinjau dalam perkembangan sejarah dakwah, pesan dakwah memiliki karakteristik yang unik dibandingkan dengan ajaran itu sendiri. Pesan dakwah terlahir sebagai produk dialogis antara tuntutan situasi sosio-kultural serta menjadi faktor pemberi makna terhadap suatu ajaran. Adakalanya ajaran Islam berinteraksi dengan budaya, sebagai sebuah pesan ajaran diurunkan dari seperangkat nilai yang terkandung dalam budaya. Karena nilai budaya itu memiliki ciri universal dan tidak bertentangan dengan Islam, maka jadilah kebudayaan itu sebagai pesan dakwah.

Hasan Al-Banna sebagai seorang tokoh pergerakan dakawah yang fenomenal, pejuang pembebasan serta pemurnian ajaran Islam, di tangannya ajaran Islam bersifat komprehensif dalam menyelsaikan permasalahan yang dialami umat manusia. Terlebih pada saat Hasan Al-Banna berdakwah, situasi umat Islam Khususnya di Mesir saat itu sedang dalam kondisi memprihatinkan sebgai dampak runtuhnya kekhalifahan Utsmaniyah. Pola pemahaman ini telah membangkitkan kesadaran dirinya untuk berjuang secara proaktif terhadap problem sosial yang menimpa umat Islam saat itu.

"Hasan Al-Banna dilahirkan di Kota kecil Mahmudiyah di muara Sungai Nil, Sembilan puluh mil di sebelah barat Kairo, pada tahun 1906, Ia dijuluki sebagai Pembaharu Islam di Abad

${ }^{1}$ Hemlan Elhany, Dakwah Islam Di Eras Globalisasi Perspekstif Bimbingan Penyluhan Islam, Jurnal Bimbingan Penyuluhan Islam Vol.1 No.2 Juli-Desember 2019 h 298-299 
20". ${ }^{2}$ Secara sosio-kultural dunia Islam pada saat penjajahan Inggris terhadap Mesir, umat Islam Mesir diibaratkan hidup dalam kegelapan bagai anak ayam yang kehilangan induknya, dari sana bermunculanlah gerakan sekularisme di setiap negara Islam yang menyebar massif bagaikan jamur di musim hujan. Tokoh-tokoh masyarakat yang berkiblat ke Barat mulai berani tampil bermunculan dan berperan mempengaruhi umat Islam. Golongan yang berkiblat ke Barat bergerak sangat aktif memproposikan paham mereka di Mesir. Ditambah dengan pergerakan emansipasi wanita semakin bertambah kuat. Para wanita kelas atas Mesir memberontak, enggan memakai jilbab. Mereka justreru memakai fashion ala Eropa, menghadiri tamasya sosial yang bercampur bebas antara lelaki dan perempuan, baik yang secara tertutup maupun yang secara terbuka. Mereka mendesak agar wanita diberi hak yang setara dengan laki-laki. Keadaan menjadi lebih parah di saat para ulama jahat yang berpihak pada pemerintah begitu mudah dipermainkan untuk kepentingannya, serta kebijakannya menyimpang dari ajaran Islam.

Kondisi tersebut menjadi latar belakang Hasan Al-Banna perlu mengemas serangkaian pesan-pesan dakwah yang berkenaan dengan gerkan dakwahnya. Gerakan dakwah Hasan Al-Banna mewujud pada terbentuknya organisasi politik bernama Ikhwanul Muslimin.

Melalui organisasi yang dibentuknya, Hasan al-Banna mengusung pentingnya pembebasan umat Islam dari pengaruh ajaran modernisasi yang berkonotasi negatif dan merugikan negara Mesir, termasuk budaya barat yang kurang sesuai dengan ajaran Islam, sehingga akan merusak moral dan tata nilai umat Islam. Dengan organisasi ini pun, Hasan Al-Banna ingin mengembalikan sisten pemerintahan yang berdasarkan Islam seperti sistem Khalifah, karena menurut pandangan mereka pemerintah yang berkuasa sudah menjadi boneka inggris dan

2 Muhammad Said Mursi, Tokoh-tokoh Besar Isalam Sepanjang Sejarah, (Jakarta: Pustaka Al-Kautsar, 2007), h. 244 
banyak dipengaruhi oleh paham libralisme dan barat, sehingga kurang memperhatikan kepentingan masyarakat Mesir."3

Hasan Al-Banna memiliki suatu cara dalam mewujudkan gagasannya tersebut, yakni mengemas pesan dakwah supaya produksi pesan dakwah yang berbeda dengan yang lainnya. Dakwah yang diserukan olehnya adalah kembali pada ajaran Islam serta menjadikan Alquran dan Hadist sebagai pedoman hidup, kemudian mengajak kepada penerapan syariat Islam dalam kehidupan nyata. Dengan gagasan tersebut Hasan AlBanna berusaha dengan gigih membendung arus sekularisasi di dunia Islam melalui pesan-pesan dakwah.

Pemikiran Hasan Al-Banna terdiri atas keadaan sosialpolitik. Pada aspek sosial, Hasan Al-Banna mengemukakan tiga elemen pembangunan manusia diantaranya; "individu muslim, keluarga muslim dan masyarakat muslim. Sumbangan pemikiran tersebut memiliki harapan dalam aspek pembangunan manusia melahirkan individu yang benar-benar berkualitas". ${ }^{4}$

Pemikiran Hasan Al-Banna dalam bidang politik terutama yang dituangkan dalam wadah Ikhwanul Muslimin. Wadah tersebut telah memberikan semangat perjuangan masyarakat Islam agar tidak tertinggal jauh dari ajaran Islam serta kembali pada kehidupan yang diinspirasi dari Alquran dan Hadist. Meskipun pembaharu Islam telah wafat, pikirannya masih ada untuk kehidupan Masyarakat Islam. ${ }^{5}$ Hasan Al-Banna menjadikan Alquran dan Hadist sebagai formulasi pesan dalam gerakan dakwah serta pembinaan kader dan masyarakat.

Fokus penelitian dalam tulisan ini adalah mengkaji pesan dakwah Hasan Al-Banna yang terdapat dalam salah satu bukunya yang berjudul "Majmu'at al-Rasail" yang terdiri atas

${ }^{3}$ A. Zaeni "Hasan Al-Banna dan Strategi Perjuangannya" dalam Jurnal Al-Adyan, (Lampung: Universitas Islam Negeri Raden Intan) No. 2/Juli 2011, h. 135-146

4 Zainudin Hasyim, dkk, "Pendekatan Hasan Al-Banna dalam Pembangunan Insan Menyusuri Majmuatu Rasail" dalam Hadhari, (Kualalumpur: Jabatan Dakwah dan Pembangunan Insan, Akademi Pengajian Islam) No. 7/Februari 2015, h. 49-62

5 Rosmaladewi, "Pemikiran Politik Hasaan Al-Banna" dalam Nuranii, (Palembang: Universitas Islam Negeri Raden Fatah) No. 2/Desember 2015, h. 75-88 
sebelas (11) topik, diantaranya: 1) Risalah kepada Apa Kami Menyeru Manusia, 2) Risalah Apakah Kita Para Aktivis, 3) Risalah Dakwah Kami, 4) Risalah Menuju Cahaya, 5) Risalah Ma'tsurat, 6) Risalah Muktamar Mahasiswa Al-Ikhwan AlMuslimin, 7) Risalah Manhaj, 8) Risalah Ta'lim, 9) Risalah munajat, 10) Risalah Muktamar Kelima dan 11) Risalah di Bawah Naungan Panji Muhammad Rasulullah. Secara khusus dalam penelitian ini adalah mengungkap bagaimana kontruksi pesan dakwah Hasan Al-Banna, mengungkap bagaimana pesan dakwah dirumuskan dan mengungkap bagaimana situasi sosial yang menyertai proses kontruksi pesan dakwah Hasan AlBanna?

Penelitian ini dilakukan dengan menggunakan analisis wacana kritis (Critical Discourse Analysis) model Norman Fairclough yang meliputi text, discourse practice serta socio-cultural practice. Analisis yang di dasari pada model Norman Fairclough mengacu pada pertanyaan besar, bagaimana menghubungkan teks yang mikro dengan konteks masyarakat yang makro.

"Model Norman Fairclough merupakan suatu model analisis wacana yang berkontribusi dalam analisis sosial dan budaya. Fairclough mengkombinasiskan tradisi analisis tekstual yang selalu melihat bahasa dalam ruang tertutup dengan konteks masyarakat yang lebih luas. Titik perhatian besar dari model ini adalah bahasa sebagai praktik kekuasaan. Model ini dibangun atas integrase analisis wacana yang berdasar pada linguistic pemikiran sosial, politik dengan perubahan sosial. Sehingga analisis harus terpusat pada bagaimana bahasa terbentuk dan dibentuk oleh relasi sosial dan konteks sosial tertentu." 6

\section{B. Pembahasan}

Pesan dakwah Hasan Al-Banna dalam tulisan ini diungkapkan dengan mengupas pemikirannya di dalam buku yang berjudul Majmuatu al-Rasail, menggunakan paradigma kritis dari Norman Fairclough. Pemikiran Hasan Al-Banna tertuang dalam buku Majmuatu al-Rasil yang tersusun berdasar pada latar belakang pendidikan dan sosio-kultural yang dialaminya. Sementara paradigma kritis yang digunakan sebagai tipe analisis,

6 Eriyanto, Analisis Wacana Pengantar Analisis Teks Media. (Yogyakarta: LKIS, 2008), h. 88. 
terutama mempelajari bagaimana kekuasaan disalah gunakan atau bagaimana dominasi serta ketidakadilan dijalankan dan direproduksi melalui teks pada sebuah konteks sosial politik. Dalam tulisan ini Hasan Al-Banna mencoba mengimbangi dengan berkontestasi dalam politik untuk mengembalikan Mesir yang berdasarkan Islam dari dominasi faham Barat.

\section{Analisis Wacana Kritis Model Norman Fairclough}

Norman Fairclough dalam analisis wacana kritis melihat wacana pada pemakaian bahasa dalam tuturan dan tulisan, sebagai bentuk dari praktik sosial. "Suatu tulisan menggambarkan wacana sebagai praktik sosial menyebabkan sebuah hubungan dialektis di antara diskursus peristiwa tertentu dengan situasi, institusi dan struktur sosial yang membentuknya. ${ }^{7}$

Analisis Norman Fairclough didasarkan pada pertanyaan besar, bagaimana menghubungkan teks yang mikro dengan konteks masyarakat yang makro. Fairclough berusaha membangun suatu model analisis wacana yang mempunyai kontribusi dalam analisis sosial dan budaya, sehingga ia mengkombinasikan tradisi analisis tekstual yang selalu melihat bahasa dalam ruang tertutup dengan konteks masyarakat yang lebih luas. Titik perhatian besar dari Fairclough adalah melihat bahasa sebagai praktik kekuasaan.

Norman Fairclough membangun suatu model yang mengintegrasikan secara bersama-sama analisis wacana yang didasarkan pada linguistik pemikiran sosial, politik, dan secara umum diintegrasikan pada perubahan sosial. Oleh sebab itu, analisis harus dipusatkan pada bagaimana bahasa itu terbentuk dan dibentuk dari relasi sosial dan konteks sosial tertentu.

Gambar I Kerangka Analisis Wacana Model Norman Fairclough $^{8}$

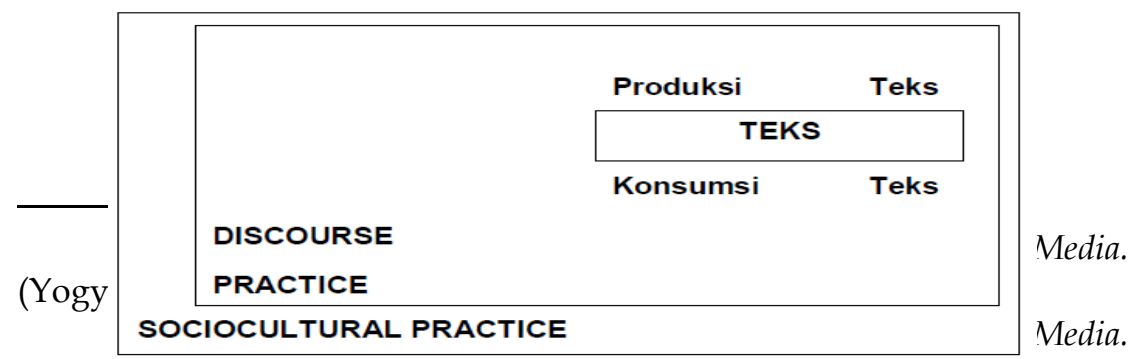

(Yogyakarta: LKIS, 2UU8), h. 288 
Setiap teks pada dasarnya, menurut Fairclough, dapat diuraikan dan dianalisis dari ketiga unsur Fairclough membagi analisis wacana dalam tiga dimensi: teks, discourse practice, dan sosiocultural practice. Dalam model Fairclough, teks di sini dianalisis secara linguistik, dengan melihat kosakata, semantik, dan tata kalimat. Ia juga memasukkan koherensi dan kohesivitas, bagaimana antarkata atau kalimat tersebut digabung sehingga membentuk pengertian.

Pertama, Fairclough melihat teks dalam berbagai tingkatan. Sebuah Teks bukan hanya menampilkan bagaimana suatu objek di gambarkan tetapi juga bagaimana hubungan antar objek didefinisikan. Ada tiga elemen dasar dalam model Fairclough, yang dapat di gambarkan dalam table berikut. Setiap teks pada dasarnya, menurut Fairclough, dapat di uraikan dan dianalisis dari ketiga unsur, teks di sini dianalisis secara linguistik, dengan melihat kosakata, semantik dan tata kalimat. Ia juga memasukkan koherensi dan kohesivitas, bagaimana antarkata atau kalimat tersebut digabung sehingga membentuk pengertian. Semua elemen yang dianalisis tersebut dipakai untuk melihat tiga masalah berikut. Pertama, ideasional yang merujuk pada representasi tertentu yang ingin ditampilkan dalam teks, yang umumnya membawa muatan ideologis tertentu. Analisis ini pada dasarnya ingin melihat bagaimana sesuatu ditampilkan dalam teks yang bisa jadi membawa muatan ideologis tertentu. Kedua, relasi, merujuk pada analisis bagaimana konstruksi hubungan diantara penulis dengan pembaca, seperti apakah teks disampaikan secara formal atau informal, terbuka atau tertutup. Ketiga, identitas, merujuk pada konstruksi tertentu dari identitas penulis dan pembaca, serta bagaimana personal dan identitas ini hendak ditampilakan. ${ }^{9}$

Kedua, analisis discourse practice memusatkan perhatian pada bagaimana produksi dan konsumsi teks. Teks di bentuk

9 Eriyanto, Analisis Wacana Pengantar Analisis Teks Media. (Yogyakarta: LKIS, 2008), h. 285-287 
lewat suatu praktik diskursus, yang akan menetukan bagaimana teks tersebut di produksi. Misalnya Wacana. Suatu praktik diskursus yang melibatkan aktifitas yang berlangsung dalam wacana. Dalam pandangan Fairclough ada dua sisi dari praktik diskursus tersebut. Yakni produksi teks (di pihak media) dan konsumsi teks (di pihak khalayak)

Ketiga, analisis sociocultural practice didasarkan pada asumsi bahwa konteks sosial yang ada di luar media mempengaruhi bagaimana wacana yang muncul dalam media. Fairclough membuat tiga level analisis pada sociocultural practice: level situasional, institusional dan sosial. Dibawah ini uraiannya:

a) Situasional, konteks sosial, bagaimana teks itu diproduksi diantaranya memperhatikan aspek situasional ketika teks tersebut diproduksi. Teks dihasilkan dalam suatu kondisi atau suasana yang khas, unik, sehingga satu teks bisa jadi berbeda dengan teks yang lain. Kalau wacana dipahami sebagai suatu tindakan, maka tindakan itu sesungguhnya adalah upaya untuk merespons situasi atau konteks sosial tertentu Institusional, Level institusional melihat bagaimana pengaruh institusi organisasi dalam praktik produksi wacana. Intitusi ini bisa berasal dari masyarakat. Artinya Ideologi masyarakat berperan dalam membentuk teks.

b) Sosial, faktor sosial sangat berpengaruh terhadap wacana yang muncul dalam pemberitaan. Bahkan Fairclough menegaskan bahwa wacana yang muncul dalam media ditentukan oleh perubahan masyarakat. Kalau aspek situasional lebih mengarah pada waktu atau suasana yang mikro (konteks peristiwa saat teks berita dibuat), aspek sosial lebih melihat pada aspek makro seperti sistem politik, ekonomi, atau sistem budaya masyarakat secara keseluruhan

\section{Biografi Singkat Hasan Al-Banna}

"Hasan Al-Banna lahir di Kota Kecil Mahmudiyah di Muara Sungai Nil, Sembilan puluh mil di sebelah barat laut Kairo Mesir pada bulan Sya'ban $1324 \mathrm{H}$, bertepatan dengan bulan 
Desember 1906 M."10 Hasan Al-Banna memiliki nama lengkap Hasan Ahmad Abdurrahman Muhammad Al-Banna, Ia dilahirkan dari keluarga yang kental dengan nuansa ke-Islaman di pedalaman Mesir tepatnya di daerah Syamsir. Ia lahir dari keluarga terhormat dan dibesarkan dalam suasana keluarga yang taat pada ajaran Islam. Sebagai seorang ayah, Syeikh Ahmad memiliki harapan terhadap anaknya (Hasan Al-Banna) sebagai mujahid atau pejuang serta sebagai seorang mujaddid atau pembaharu. Diusianya yang masih belia Ia dituntut untuk menghafal Alquran. Hasan Al-Banna didaftarakan pada Sekolah persiapan yang dirancang pemerintah Mesir, semacam Sekolah Dasar namun tanpa pelajaran bahasa asing. Jika Ia di rumah, Ia tetap bergelut dengan buku-buku yang ada di perpustakaan pribadi milik ayahnya. Di perpustakaan pribadinya itu tersedia buku-buku tentang agama, hokum, hadist dan ilmu bahasa.

Hasan al-Banna sangat antusias dalam memperluas cakrawala keimuannya. Ia mulai menghafal banyak matan kitab berbagai disiplin ilmu, seperti Milh\}at al-I'rab karya al-Hariri, Alfiyyah karya Ibnu Malik, al-Yaqutiyah kitab Mustalah Hadis, Jauharah at-Tauhid, Rahabiyyah, as-Sullam, berbagai matan alQaduri kitab fikih Abu Hanifah, Matan Gayah wa at-Taqrib karya Abu Syuja' kitab fikih Syafi'iyyah, dan beberapa Manzuumah Ibnu Amir tentang fikih Malikiyyah. Ayahandanya senantiasa memotivasi dengan ungkapannya yang menyentuh, "Siapa rajin menghafal matan, ia akan menguasai berbagai disiplin ilmu'. Tidak heran, jika Ia dari kecil sudah begitu mencintai ilmu dan memiliki wawasan yang luas. ${ }^{11}$ Dalam suasana keluarga yang dipenuhi ketakwaan dan keilmuan, Ia tumbuh berkembang. Kemudian melanjutkan sekolah dari madrasah Addadiyah ke Daarul Muallimin di daerah Damanhur tahun 1920. Hasil belajarnya Ia selsai menghapalkan Alquran di usia 14 tahun.

Ketika usianya enam belas (16) tahun, Hasan Al-Banna pergi ke Kairo untuk melanjutkan sekolah guru bahasa Arab,

10 Abdul. Kholik, Pemikiran Pendidikan Islam Kajian Tokoh Klasik dan Kontemporer. (Semarang: UIN Walisongo dengan Pustaka Pelajar, 2009), h. 253

11 Ahmad Hasan asy-Syurbaji, al-Imam asy-Syaahid Hasan alBanna Mujaddid al-Qarn ar-Ra>bi' Asyr al-Hijry, cet. ke-1 (Iskandariyah: Daar ad-Dakwah: 1998), h. 46. 
sebuah lembaga pendidikan abad pembaharu yang berdiri pada abad ke-19. Dalam lingkungan pendidikan tersebut Ia mempu mengorganisasikan kelompok mahasiswa di Universitas AlAzhar dan kelompok mahasiswa Dar al-Ulum yang melatih diri berkhotbah di masjid-masjid. Dalam kesempatannya belajar di Kairo, Ia sering berkunjung ke toko-toko buku yang dimiliki gerakan Shalafiyah oimpinan Rasyid Ridha. Di Mesir Ia juga aktif membaca kitab tafsir al-Manar dan berkenalan dengan Rasyid Ridha. Tidak berhenti sampai di sana Ia juga menjalin komunikasi dengan para murid Muhammad Abduh. Hasan AlBanna lulus tahun $1345 \mathrm{H}$ atau $1927 \mathrm{M}$ di Darul Ulum dan mendapat rangking pertama.

Setelah lulus Hasan Al-Banna diangkat menjadi guru di Ismailiyah Terusan Suez, dari sanalah terlahir bibit-bibit organisasi Ikhwan Al-Muslim. Kemudian terbentuklah organisasi pada bulan Zulqaidah $1347 \mathrm{H}$ bertepatan dengan 1928 M. Pada tahun 1932 M, Hasan Al-Banna pindah ke Kairo, dengan begitu berpindah pula markas atau sekretariat Ikhwan Al-Muslim ke kota tersebut. Saat itulah organisasi Ikhwan Al-Muslim ikut membesar. Seiring dengan kebiasaan berdakwahnya yang unik, yaitu dengan duduk di kedai kopi dan berbincang dengan para pemuda membahas permsalahan sosial yang terjadi di negeri Mesir. Kesuksesan dakwahnya dianggap oleh colonial Inggris sebagai ancaman serius bagi kelangsungan kekuasaan. Penguasa akhirnya menyingkirkan Hasan Al-Banna dari kancah politik serta berbagai cobaan yang menimpa anggota Ikhwan Al-Muslim mulai dari penangkapan, penahanan, penyiksaan hingga pada pembunuhan. Puncaknya pada tanggal 12 Februari 1949 bertepatan 14 Rabiul Akhir 1367 H, Hasan Al-Banna ditembak orang yang tidak dikenal, sempat ke rumah sakit namun tidak satu pun dokter yang mau menolongnya, dua jam berselang Ia menghembuskan nafas terakhir dengan tubuhnya yang tersungkur dan belumuran darah.

Masa mudanya dihabiskan untuk mencari ilmu, setelah belajar Ia membantu ayahnya yang berprofesi sebagai ahli reparasi jam yang menuntut kejelian, kesabaran dan keteraturan. "Aktivitas dakwahnya bermula saat Ia berusia dua belas (12) tahun, di usia yang masih tanggung Ia memiliki ketertarikan 
dengan masalah-masalah keagamaan"12, Ia pun bergabung denga organisasi masyrakat yang mempelajari tingkahlaku dan moral. Hasan Al-Banna kecil mendisiplinkan waktunya menjadi empat waktu. Siang hari dipergunakan untuk belajar di Sekolah dan membantu orangtuanya hingga sore hari, waktu sore menjelang tidur digunakan untuk mengulang pelajaran sekolah, sementara membaca dan mengulang-ngulang hafalan Alquran Ia lakukan setelah solat subuh. "Dengan dukungan dari ayahnya, yang juga seorang ulama ahli fiqih, ahli hadist, menjadi imam masjid serta menulis beberapa kitab."13 Selain ayahnya, Hasan Al-Banna mendapatkan pendidikan dari gurunya sewaktu di Damanhur yakni Syeikh Zahran yang selalu menggunakan sentuhan batin dalam mendidik murid-muridnya. "Jiwanya yang selalu berkobar untuk membakar kecurangan-kecurangan yang Hasan Al-Banna anggap harus dihapuskan, kecerdasannaya yang tak pernah berhenti memikirkan berkembang, hingga carannya masalah yang terkadang sering dilupakan oleh banyak pihak di zaman sekarang." 14

\section{Gambaran Umum Majmuat al-Rasail}

Majmu'at al-Rasail adalah karya monumental Imam Hasan Al-Banna yang menjadi rujukan penting bagi pergerakan Ikhwanul Muslimin. Sebuah pergerakan yang memberikan inspirasi bagi kebangkitan kaum muslimin di berbagai negara; berisi kumpulan surat, makalah, dan transkrip pidato yang pernah dibuat dan disampaikan oleh Hasan Al- Banna sepanjang hidupnya di medan dakwah dan jihad. Buku Majmu'at al-Rasail terdiri dari sebelas (11) bab yaitu: 1) Risalah kepada Apa Kami Menyeru Manusia, 2) Risalah Apakah Kita Para Aktivis, 3) Risalah Dakwah Kami, 4) Risalah Menjuju Cahaya, 5) Risalah Ma'tsurat, 6) Risalah Muktamar Mahasiswa Al- Ikhwan Al-Muslimun,7) Risalah

12 Herry Mohammad dkk, Tokoh-tokoh Islam yang Berpengaruh Abad 20. (Jakarta: GemaInsani Perss. 2006), h. 202

13 Ramayulis dan Nizar, S. Ensiklopedi Tokoh Pendidikan Islam. (Jakarta: Quantum Teaching, 2005), h. 85

14 Iin Masniyah, "Tujuan Pendidikan Islam dan Gerakan Ikhwanul Muslimin Munurut Hasan Al-Banna" dalam Jurnal Istoria: Jurnal Pendidikan dan Sejarah (Yogyakarta: Universitas Negeri Yogyakarta, Fakultas Ilmu Sosial, Prodi Pendidikan Sejarah) No. 2/September 2019, h. 140-159 
Manhaj, 8) Risalah Ta'lim, 9) Risalah Munajat, 10) Risalah Muktamar Kelima dan 11) Risalah di Bawah Naungan Panji Muhammad Rasulullah.

Dari sebelas bab tersebut, beberapa statemen menarik dianalisa. Pertama, mandat suci itu berarti pengorbanan bukan pemanfaatan. Dalam pencapaian tugas suci, kaum muslimin rela menjual jiwa dan hartanya kepada Allah Swt. Atas dasar iman mereka tidak merasa berhak lagi atas jiwa dan hartanya. Keduanya telah menjadi wakaf dijalan Allah demi mensukseskan dakwah dan menyampaikan kepada segenap hati manusia.

Kedua, apakah kita para aktivis? Jama'ah aktif adalah jamaah yang banyak menyelenggarakan proyek-proyek yang berorientasi pada kemaslahatan sosial. Standar yang dijadikan tolak ukur bagi jama'ah dan untuk mengukur sejauh mana usaha kongkrit yang dilakukan dalam konteks kebangkitan umat ${ }^{15}$.

Ketiga, empat golongan objek dakwah: mukmin, golongan ragu-ragu, pencari keuntungan dan golongan berprasangka buruk. Perlakuan terhadap golongan mukmin, Ikhwanul Muslimin mengajak mereka untuk segera bergabung dan bekerja sama agar jumlah para mujahid semakin banyak; perlakuan kepada yang ragu-ragu, biarkanlah mereka bersama keraguannya, sembari disarankan agar mereka tetap berhubungan dengan kami lebih dekat lagi, membaca tulisan-tulisan kami dan apa saja yang terkait dengan kami baik dari jauh maupun dari dekat, mengunjungi klub-klub kami; perlakuan kepada golongan yang mencari keuntungan, kami hanya ingin mengatakan, "Menjauhlah! Disini hanya ada pahala dari Allah jika kamu memang benar-benar ikhlas, dan surgaNya jika ia melihat ada kebaikan dalam hatimu. Adapun kami, adalah orang-orang yang miskin harta dan popularitas; sedangkan perlakuan kepada golongan yang berprasangka buruk, hatinya diliputi keraguan. Mereka selalu melihat kami dengan kacamata hitam pekat, dan tidak berbicara tentang kami kecuali dengan pembicaraan yang sinis, kami mendo'akannya.

15 Hasan Al-Banna, Majmuatu Rasail. (Mesir: Al-Bashair Li alBuhuts wa ad-Dirosat, 2012), h. 97 
Keempat, Islam menjamin kebutuhan bangsa yang bangkit. Umat yang tengah bangkit membutuhkan cita- cita yang luhur. Alquran telah memberikan jawabannya untuk memenuhi tuntutan cita-cita tersebut dengan metodologi yang mampu mengubah umat yang jumud menjadi dinamis, penuh semangat untuk meraih cita-cita dan memiliki tekad kuat untuk membangun dirinya. Umat yang tengah bangkit membutuhkan rasa bangga terhadap bangsanya, bangga sebagai umat yang utama dan mulia, yang memiliki berbagai keistimewaan dan perjalanan sejarah yang indah, sehingga kebanggaan ini akan tertanam pula dalam jiwa generasi penerusnya. Umat yang tengah bangkit pasti membutuhkan kekuatan yang besar dan jiwa keprajuritan putra-putranya. Apalagi dimasa sekarang, dimana tidak ada sesuatu pun yang dapat menjamin tegaknya perdamaian, kecuali kesiapan untuk berperang. Bahkan masyarakat telah akrab dengan slogan "kekuatan adalah cara yang paling menjamin tegaknya kebenaran". Setelah kita sadari bahwa bangsa yang tengah bangkit membutuhkan jiwa keprajuritan yang tinggi maka ketahuilah bahwa salah-satu dari pilar yang menyangga jiwa keprajuritan adalah sehat dan kuat jasmaninya. Islam mendorong sepenuhnya berbagai kegiatan ilmiah seperti penelitian dan penyusunan karya ilmiah. Islam sekali lagi tidak abai terhadap Ilmu Pengetahuan, bahkan menjadi aktivitas ilmiah sebagai salah satu kewajiban diantara kewajiban-kewajiban yang lain. Umat yang tengah bangkit sangat membutuhkan akhlak yang mulia, jiwa yang besar an citacita yang tinggi. Karena umat tersebut akan menghadapi berbagai tuntutan dari sebuah masyarakat baru: suatu tuntutan yang tidak mungkin dipenuhi kecuali dengan kesempurnaan akhlak dan ketulusan jiwa yang lahir dari iman yang menghujam dalam dada, komitmen yang menancap kuat didalam hati, pengorbanan yang besar dan mental yang tahan uji. Umat yang tengah bangkit juga sangat membutuhkan penanganan atas urusan ekonominya. Karena Ia persoalan paling penting di masa kini. ${ }^{16}$

Kelima, al-ma'tsurat. Bahwa setiap manusia itu mempunyai tujuan asasi dalam kehidupannya, seluruh pemikiran diarahkan kesana dan kesana pula tertuju semua amal perbuatan serta

${ }^{16}$ Hasan Al-Banna....h 253 
semua angan dan cita-citanya. Tujuan Asasi itulah yang banyak orang menamakan dengan al-matsalul a'la (nilai yang tinggi). Kapan saja tujuan ini meninggi dan melambung nilainya maka akan naik pula amal perbuatan yang tinggi dan agung. Jiwa pemiliknya akan terhormat dengan sebuah bentuk keindahan ruhani dan selalu meniti menuju kesempurnaan, sampai akhirnya tergapai apa yang diinginkan al-Banna. ${ }^{17}$

Keenam, menuju amal. Bahwa sudah saatnya kita meninggalkan medan kata-kata menuju medan amal, dari medan penentu strategi dan manhaj menuju medan penerapan dan realisasi. Telah sekian lama kita menghabiskan waktu dengan hanya sebagai tukang pidato dan ahli bicara, sementara zaman telah menuntut kita untuk segera mempersembahkan amal-amal nyata yang professional dan produktif. Ketujuh, al-marahil. Dalam tulisan ini diurai tiga tahapan dakwah yaitu: ta'rif (pengenalan), takwin (pembentukan) dan tanfidz (pelaksanaan) atau dengan kata lain dakwatu- ammah (dakwah umum), dakwatu- khassah (dakwah khusus), amal (perubahan tradisi), i'dad (persiapan) dan itmam (penyempurnaan). ${ }^{18}$

Kedelapan, amal. Maksudnya bahwa amal merupakan buah dari ilmu dan keikhlasan. "Dan katakanlah, 'Bekerjalah kamu, maka Allah dan Rasul-Nya serta orang-orang mukmin akan melihat pekerjaanmu itu, dan kamu akan dikembalikan kepada (Allah) Yang Mengetahui yang ghailb dan yang nyata, lalu diberitakan-Nya kepada kamu apa yang telah kamu kerjakan,"' (At-Taubah: 105). Adapun tingkatan amal yang dituntut dari seorang $a k h$ yang tulus adalah:

Perbaikan diri sendiri, sehingga ia menjadi orang yang kuat fisiknya, kokoh akhlaknya, luas wawasannya, mampu mencari penghidupan, selamat akidahnya, benar ibadahnya, pejuang bagi dirinya sendiri, penuh perhatian akan waktunya, rapi urusannya, dan bermanfaat bagi orang lain. Itu semua harus dimiliki oleh masing-masing $a k h$; Pembentukan keluarga muslim, yaitu dengan mengkondisikan keluarga agar menghargai fikrahnya, menjaga etika Islam dalam setiap aktivitas kehidupan

\footnotetext{
17 Hasan Al-Banna, ...h 297

18 Hasan Al-Banna, ...h 298
} 
rumah tangganya, memilih istri yang baik dan menjelaskan kepadanya hak dan kewajibannya, mendidik anak-anak dan pembantunya dengan didikan yang baik, serta membimbing mereka dengan prinsip-prinsip Islam; Bimbingan masyarakat, yakni dengan menyebarkan dakwah, memerangi perilaku yang kotor dan munkar, mendukung perilaku utama, amar ma'ruf, bersegera mengerja- kan kebaikan, menggiring opini umum untuk memahami fikrah islamiyah dan mencelup praktek kehidupan dengannya terus-menerus. Itu semua adalah kewajiban yang harus ditunaikan oleh setiap akh sebagai pribadi, juga kewajiban bagi jamaah sebagai institusi yang dinamis; Pembebasan tanah air dari setiap penguasa asing non-Islam- baik secara politik, ekonomi, maupun moral; Memperbaiki keadaan pemerintah, sehingga menjadi pemerintah Islam yang baik. Dengan begitu ia dapat memainkan perannya sebagai pelayan umat dan pekerja yang bekerja demi kemaslahatan mereka. pemerintah Islam adalah pemerintah yang anggotanya terdiri dari kaum muslimin yang menunaikan kewajiban-kewajiban Islam, tidak berterang terangan dengan kemaksiatan, dan konsisten menerapkan hukum-hukum serta ajaran Islam. Tidaklah mengapa menggunakan orang-orang non-Islam jika dalam keadaan darurat asalkan bukan untuk posisi jabatan strategis. Tidak terlalu penting mengenai bentuk dan nama jabatan itu, selama sesuai dengan kaidah umum dalam sistem undang-undang Islam, maka boleh. Beberapa sifat yang dibutuhkan antara lain: rasa tanggung jawab, kasih sayang kepada rakyat, adil terhadap semua orang, tidak tamak terhadap kekayaan negara, dan ekonomis dalam penggunaannya. Beberapa kewajiban yang harus ditunaikan antara lain: menjaga keamanan, menerapkan undang-undang, menyebarkan nilai-nilai ajaran, mempersiapkan kekuatan, menjaga kesehatan, melindungi keamanan umum, mengembangkan investasi dan menjaga kekayaan, mengokohkan mentalitas, serta menyebarkan dakwah; Beberapa haknya tentu, jika telah ditunaikan kewajibannyaantara lain loyalitas dan ketaatan, serta pertolongan terhadap jiwa dan hartanya. Apabila ia mengabaikan kewajibannya, maka berhak atasnya nasehat 
dan bimbingan, lalu -jika tidak ada perubahan- bisa diterapkan pemecatan dan pengusiran. Tidak ada ketaatan kepada makhluk dalam bermaksiat kepada Khaliq; Usaha mempersiapkan seluruh aset negeri di dunia ini untuk kemaslahatan umat Islam. Hal demikian itu dilakukan dengan cara membebaskan seluruh negeri, membangun kejayaannya, mendekatkan peradabannya, dan menyatukan katakatanya, sehingga dapat mengembalikan tegaknya kekuasan khilafah yang telah hilang dan terwujudnya persatuan yang di impi-impikan bersama; Penegakan kepemimpinan dunia dengan penyebaran dakwah Islam di seantero negeri.

Kesembilan, munajat. Berisi keutamaan qiyamulail dan doa dan istigfar serta hal-hal lain yang sejalan dengan itu. Juga tentang doa-doa maetsur pilihan. Semoga itu dapat mengingatkan mereka tentang adab-adab yang disunahkan serta menjadi penuntun tentang tatacara yang diperintahkan.

Kesepuluh, sebagian karakter dakwah ikhwan. Diantara karakteristik dakwahnya itu: menjauhi titik-titik khilafiyah, menjauhi dominasi tokoh dan pembesar, menjauhi fanatisme partai dan golongan,memperhatikan masalah takwin (pembentukan kepribadian) dan tadarruj (bertahap) dalam langkahlangkahnya, mengutamakan sisi amaliyah yang produktif diatas seruan-seruan dan propaganda-propaganda kosong, diterima dengan sangat baik oleh generasi muda, cepat berkembang dipedesaan dan perkotaan.

Kesebelas, al-ikhwan al-muslimun di bawah panji alQuran. ${ }^{19}$ Pada saat ramai terdengar jeritan yang berkumandang dari relung tragedy kemanusiaan yang getir dan memilukan yang lahir dari rahim kegelapan zaman ini, diarus kehidupan yang memancar dari teriakan prihatin seluruh alam, yang dibawa oleh gelombang lembut menyusup ke berbagai penjuru kehidupan yang dapat mematikan secara mengejutkan segala impan, janji-janji dan fenomena yang menipu serta penuh kepalsuan. Kami persembahkan dakwah ini, Dakwah Ikhwanul Al Muslimun yang tenang, namun lebih gemuruh dari tiupan angina topan yang merdu. Dakwah yang rendah hati, namun

${ }^{19}$ Hasan Al-Banna, ....h. 230 
lebih tegar dari gununggunung tinggi yang kokoh berdiri. Dakwah yang terbatas, namun jangkauannya lebih luas dari belahan bumi seluruhnya. Ia sepi dari prilaku yang menipu dan gemerlap yang penuh dusta. Namun, ia dikemas oleh keagungan hakikat, keagungan wahyu dan pemeliharaan Allah. Demikianlah, ia bersih ari berbagai kerakusan nafsu dan kepentingan pribadi. Tapi ia mampu mewariskan kedaulatan di dunia dan disurga diakherat bagi mereka yang percaya padanya dan tulus bekerja untuknya.

\section{Wacana Pesan Dakwah Hasan Al-Banna}

Wacana pesan dakwah dalam Majmu'at al-Rasail Hasan AlBanna terbagi kepada pesan dakwah akidah, pesan dakwah syariah dan pesan dakwah akhlak. Pertama, Pesan Dakwah Akidah dalam Wacana Teologi. Hasan Al- Banna, mencoba membuka pikiran akan arti kehidupan setiap manusia dengan nilai Ketuhanan. Hasan Al-Banna berusaha membangun secara sistematik (systematic reconstruction) bidang teologi, filsafat dan ilmu-ilmu sosial dalam wilayah pemikiran Islam. Hasan AlBanna mencoba keluar dari ruang perkembangan yang sempit, membuka diri kepada kemodernan sehingga mampu menjawab tantangan zaman. Pembahasan akidah bukan saja tertuju pada masalah-masalah yang wajib diimani, akan tetapi juga meliputi masalah-masalah yang dilarang sebagai lawannya, misalnya syirik (menyekutukan Allah), ingkar dengan adanya Tuhan. Semua itu Hasan Al-Banna ungkapkan sebagai bahan untuk menjadikan sistem kemasyarakatan yang memurnikan akidah dalam kehidupannya.

Kesadaran Ketuhanan hendaknya menggiring masyarakat baik sebagai aktivis organisasi maupun masyarakat umum untuk senantiasa mengagungkan Allah Swt. Pernyataan ini merupakan bagian dari isyarat dalam menguatkan gerakan dengan nilai nilai ketuhanan dan menjadi suatu pengingat akan tujuan sesungguhnya dari pencapaian hidup. Nilai keimanan sebagai wahana penting bagi pelaku dakwah dalam menginternalisasi ajaran Islam.

Titik kelemahan pemikiran teologi Islam klasik terletak pada kekurangan yang dimiliki terkait kenyataan atau realitas sosial empirik kehidupan manusia yang selalu tumbuh dan berkembang sejalan dengan pertumbuhan ilmu pengetahuan dan 
teknologi. Maka dari itu, seorang pemikir Islam abad ke-20 seperti Fazlur Rahman menggarisbawahi perlunya pembangunan secara sistematik (systematic reconstruction) dalam bidang teologi, filsafat dan ilmu-ilmu sosial dalam wilayah pemikiran Islam.

Berbagai persoalan yang rumit bermunculan di tengah masyarakat modern seperti kemiskinan, penindasan, kebodohan, keterbelakangan, ketidak adilan dan sederet persoalan lain. Disadari atau tidak, literature pemikiran umat berkutat pada teologi Islam klasik, masih belum beranjak dari rumusan persoalan teologi abad tengah seperti persoalan qadariyah dan jabariyah, sifat dua puluh Tuhan, apakah Al-Qur'an makhluk atau tidak? dan seterusnya.

Pemikiran Hasan Al-Banna menjadi jembatan untuk kesehatan spiritual. Kesehatan spiritual merupakan suatu cara hidup yang dapat dipraktikkan yang menyediakan suatu alternatif dalam menghindarkan kebiasaan melakukan penyembahan tradisional terhadap arwah pemujaan roh dan kedermawanan semu. Kesehatan spiritual melibatkan adanya meditasi, kesadaran untuk saling menghormati dan saling mengasihi. Ini merupakan suatu jalan untuk dapat menyatakan kembali suatu kesadaran akan betapa pentingnya atau berharganya perjanan jiwa dalam suatu kehidupan.

Menyediakan suatu alternatif dalam menghindarkan kebiasaan melakukan penyembahan tradisional terhadap arwah pemujaan roh dan kedermawanan semu. Kesehatan spiritual melibatkan adanya meditasi, kesadaran untuk saling menghormati dan saling mengasihi. Ini merupakan suatu jalan untuk dapat menyatakan kembali suatu kesadaran akan betapa pentingnya atau berharganya perjanan jiwa dalam suatu kehidupan.

Kedua, Pesan Dakwah Syariah dalam Wacana Kekuasaan. Runtuhnya Khilafah Islamiyah telah mempengaruhi situasi politik, pemikiran, keagamaan dan sosial. Mustafa Kamal bersama para pendukungnya manjadi Khalifah (pemimpin) sangat dzalim, melakukan kudeta dan menghapuskan Khilafah Islamiyah di Turki dan menggantikan sistem negara menjadi sebuah negara republik pada tanggal 26 Rajab $1342 \mathrm{H}$, bertepatan dengan tanggal 2 Maret $1924 \mathrm{M}$. 
Dampak keruntuhan kekhalifahan Usmaniyah berimbas ke Mesir. Saat jatuh ke tangan Mustofa Kamal, Mesir tunduk kepada penjajah Inggris yang secara tidak langsung telah merampas negeri dan merampok hasil buminya. Mesir telah dirampas hasil buminya oleh inggris, sehingga keadaan ini membuat rakyat Mesir berjalan di belakang biskuit dan roti dengan perasaan remuk tanpa kekuatan apapun. Sementara kaum elit seperti para penguasa dan pejabat kerajaan bersenang-senang di atas penderitaan rakyat jelata.

Sistem yang berlaku di Mesir waktu di bawah raja Faruk, menganut system monarchi atau kerajaan. Dalam sistem ini, kepala negara ditentukan melalui garis keturunan tanpa musyawarah. Bagi Hasan Al-Banna, ini merupakan awal penyakit masyarakat, merupakan penyimpangan umat dari citacita Islam semula yaitu masa Nabi Muhammad SAW. Karena dalam Islam, hanya mengakui kepemimpinan umat yang didasarkan pada bay'ah dan syura, dan Islam tidak mengakui kepemimpinan yang didasarkan melalui garis keturunan. "Kemerosotan peranan politik dan peradaban Islam tidaklah menyebabkan hilangnya sistem ajaran Islam sebagai suatu sistem nilai yang telah merasuk kekalbu kaum muslimin, dan bahkan memberikan rembesan tumbuhnya embrio peradaban Barat modern." 20

Syariah Islam harus ditegakan dengan wasilah kekuasaan. Islam itu mencakup semua peraturan, mulai dari peraturan ibadah, muamalah dan perekonomian, peraturan ahwal syakhsiyyah (hukum keluarga), peraturan politik dan peradilan, peraturan sosial, peraturan hisbah, peraturan jihad, dan seterusnya. Syariat Islam yang tidak bisa dipisahkan untuk kemaslahatan hidup manusia. Hal ini mempunyai substansi dan agenda akhir yang sama, yakni menegakkan politik Islam, di mana syariat Islam harus dijadikan sebagai konstitusi (UUD) negara. "Disebabkan oleh ruang lingkup dari ajaran Islam yang tidak memungkinkan apabila tidak menyentuh lingkup politik dan negara. Serta ajaran Islam mengatur urusan-urusan yang memerlukan kekuasaan sebagai pelaksanaannya. Sehingga

20 Rodiyah, Sejarah Perkembangan Ikhwanul Muslimin dan Kontribusinya dalam Dakwah Islam dalam Jurnal Ath-Thariq: Jurnal dakwah dan Komunikasi (Lampung: IAIN Metro) No. 1/Juni 2019, h. 3-28 
Agama dan negara sejatinya memiliki hubungan yang tidak terpisahkan." 21

Pada saat suasana seperti ini, lahir pula berbagai partai yang memberikan loyalitas terhadap Inggris. Partai yang lahir pada masa ini mampu mengubah opini masyarakat dengan slogan-slogan yang berkaitan dengan jiwa nasionalisme. Seperti kata tsurah (revolusi) diganti dengan kata muwafadhah (perundingan), kata mu'tsmir diganti dengan kata halif (sekutu). Partai-partai tersebut tidak mempunyai program atau tujuan yang ingin dicapai selain usaha mendapatkan kursi kekuasaan guna merealisasikan kepentingan pribadi dan anggota-anggot

Partai politik harus berlandaskan syariat Islam. Hasan alBanna menolak partai politik sekuler dan nasionalis. Hasan alBanna juga merefleksikan pentingnya reformasi politik dalam negeri Mesir. Reformasi politik penting sebagai strategi untuk menghadapi pemerintah kolonial Inggris. Hasan al-Banna menyerukan agar Muslim bersatu dan meninggalkan perpecahan partai, untuk lebih fokus dalam membentuk realitas politik yang lebih islami dengan menyerukan penerapan syariat Islam, menjelaskan hubungan antara agama dan politik, serta menyeru kepada penguasa, kepala negara dan para pejabat negara akan pentingnya reformasi politik dan melihat ulang kebebasan berekspresi. Hasan Al-Banna dengan situasi kondisi yangada merancang konsep yang menjadi tawaran oleh para pelaku dakwah (da'i).

Negara merupakan instrumen untuk menegakan Syariat Islam. Islam merupakan Agama yang mempunyai arti luas, Hasan Al -Banna meyakini bahwa Islam mengatur seluruh sendisendi kehidupan umat manusia seluruhnya. Hasan Al-Banna mengungkapkan dalam wacana tersebut bahwa Islam tidak bisa dipisahkan dalam setiap aspek kehidupan. Hassan al-Banna menempatkan nasionalisme sebagai alat dan media keberhasilan menerapkan syariat Islam sebagai tujuan dari pergerakan dakwah. Hasan al-Banna menggerakkan Ikhwanul Muslimin sebagai kekuatan politik yang mengakar di Mesir. Hasan al-

${ }^{21}$ Ridwan, "Hubungan Islam dan Politik di Indonesia Perspektif Pemikiran Hasan Al-Banna" dalam Jurnal Samudra Keadilan (Malang: Universitas Muhammadiyah Malang) No. 2/Desember 2017, h. 223-236 
Banna juga mendiskusikan problem dunia Islam, dan menyerukan pentingnya persatuan umat Muslim di Indonesia, Pakistan, India, Yaman, Suriah, Libya, Maroko, Sudan, Palestina dan negara Muslim lain. Hasan al-Banna yakin adanya konspirasi global baik melalui gerakan zionis maupun koalisi Kristen Barat yang menyebabkan umat Muslim tertindas dan terjajah, termasuk seruannya dalam membela Palestina melawan Israel sejak awal perang Arab-Israel. Gerakan Hasan Al-Banna menginspirasi gerakan politik Islam dan jihad regional di Timur Tengah dan dunia Islam.

Ketiga, Pesan Dakwah Akhlak dalam Wacana Relasi Sosial. Hasan Al- Banna sangat prihatin dengan akibat negatif pengaruh modernisasi sekuler Barat pada kehidupan dan nilai-nilai Islam serta kelemahan pemerintah yang kurang tanggap dalam menghadapi kesenjangan sosio-ekonomi masyarakat Mesir. Hal ini mengilhami Hasan Al-Banna untuk bergerak, dengan kemampuan yang diberikan Allah kepadanya ia mengubah kondisi menjadi ladang yang subur bagi dakwahnya.

Kondisi ini sangat memprihatinkan, terutama dari segi moralitas sangat menurun. Banyak penulis yang dibayar oleh pihak barat untuk meneriakan dan mengikuti budaya barat, baik dan buruknya, manis dan pahitnya. Dalil kebebasan individu telah menyesatkan banyak orang dari akhlak Islami. Kedai-kedai tempat minum arak dan perbuatan mesum dibuka. Tempattempat maksiat dan diskotik dibuka dengan kemudahan yang diberikan pemerintah. Gedung-gedung bioskop dan media porno digemari.

Kondisi itulah yang membuat Hasan Al-Banna menguatkan komitmennya untuk berjihad dengan pemikiran dakwah yang dimilikinya, untuk mengumpulkan seluruh kekuatannya melawan kaum penjajah dan penguasa dzalim serta untuk mengembalikan kembali Khalifah Islamiyah yang sempat runtuh. Hasan Al-Banna memandang penting penguatan persuadaraan sesama umat Islam. Persaudaraan dalam Islam menjadi bagian penting dan tidak bisa dipisahkan sehingga perlu rambu-rambu yang dipahami tentang apa saja penyebab persaudaraan itu luntur. Penekanan ini tampak dari pemikirannya yang berupaya untuk senantiasa merangkul seluruh umat muslim dengan segala perbedaan, menjauhi hal-hal 
yang dapat memecah persatuan umat memprioritaskan hak masyarakat atas hak individu sebagai asas kemanfaatan dan pemberdayaan dengan mengutamakan persaudaraan, tolong menolong ( $\left.\boldsymbol{t a}^{\prime} \boldsymbol{a} \boldsymbol{w} \boldsymbol{w} u \mathbf{n}\right)$, empati dan rasa saling mencintai terhadap sesama muslim. Kajian akhlaq juga menekankan pentingnya amar ma'ruf nahi munkar bersumber pada tanggung jawab dan persaudaraaan yang berdasar pada keimanan.

Gagasan Hasan Al-Banna tentang pesan dakwah melalui akhlak adalah aktualisasi pemikiran Hasan Al-Banna melalui gerakan dakwah tarbiyah adalah melalui proses penyiapan manusia yang shalih, yakni agar tercipta suatu keseimbngan dalam proteksi, tujuan, ucapan dan tindakannya secara keseluruhan. Eksistensi jama'ah Tarbiyah jika dilihat dari formalitasnya sejalan dengan perkembangan jaman sudah mulai memudar karena sudah lahir berbagai gerakan massa lainnya. ${ }^{22}$

Pesan Akhlak dalam Konteks Sosio-Kultural merupakan bagian yang tidak terpisahkan dalam kegiatan dakwah Ikhwanul Muslimin, mensosialisasikan pembangunan bidang sosial pada masyarakat sebagai bentuk implementasi nilai dakwah. Kaum muslimin rela menjual jiwa dan hartanya kepada Allah Swt. Dengan keimanannya, mereka tidak merasa berhak lagi atas jiwa dan hartanya. Keduanya telah menjadi wakaf dijalan Allah demi mensukseskan dakwah dan menyampaikan kepada segenap hati manusia. Firman Allah QS. At-Taubah: 111, Sesungguhnya Allah telah membeli dari orang-orang mukmin, diri dan harta mereka dengan memberikan surga untuk mereka. Wacana tersebut adalah bagian dari bentuk internalisasi nilai yang terkandung dalam relasi sosial yang dibangun atas pemikiran Hasan Al-Banna. Bagaimana hubungan antara anggota Ikhwanul Muslimin dengan masyarakat secara luas. Namun perlu diperhatikan aspek yang berkaitan dengan perbedaan budaya, sebab tidak bisa dipungkiri bahwa perbedaan budaya salah satu penyebab gangguan dalam komunikasi untuk internalisasi dakwah.

22 Samian Hadisaputra, Kontekstualisasi Pemikiran Dakwah Hasan Al-Banna dalam Jurnal Aqlania, (Banten: UIN Sultan Maulana Hasanudin) No. 1/Juni 2017, h. 1-19 


\section{Kesimpulan}

Pesan dakwah Hasan Al-Banna yang termuat dalam Majmuat al-Rasail mencakup pesan akidah, syari'ah dan akhlaq. Pesan ini dianalisis dengan pendekatan analisis Norman Forlaigh ditemukan bahwa pesan akidah HasanAl-Banna mengisyaratkan pentingnya pembersihan akidah dari unsur syirik, serta akidah yang benar hingga mampu menggerakan semangat rela berkorban, dan mampu mengejewantahkan teologi yang benar dalam perilaku serta sikap kritis terhadap situasi yang menyeleweng. Pesan syariah mengingatkan pentingnya kekuasaan yang dibangun atas landasan Islam, sistem politik Islam yang terbebas dari system yang diperkenalkan penjajah Inggris. Sementara itu pesan akhlaq, memperbaiki kembali kondisi pola perilaku yang rusak karena modernisasi ala barat serta perilaku a-moral yang merusak pola hubungan sosial.

Secara umum pesan dakwah Hasan Al-Banna merupakan reaksi Hasan Al-Banna atas situasi negara muslim yang memprihatikan, hidup dalam keterjajahan telah mengkerangkeng kebebasan, serta semakin jauhnya cita-cita Islam menampakan wajahnya. Ini seperti terjadi di Mesir. Dengan modal kecerdasan dan pengalaman pengasuhan yang memadai dalam didikan Islam yang ketat, membuat jiwa kekritisan Hasan Al-Banna bangkit serta muncul kesadaran untuk mengembalikan segala keadaan sesuai prinsip risalah Islam. Kesadaran itu mewujud menjadi gerakan Ikhwanul Muslimin dengan kekuatan yang diperhitungan di beberapa belahan dunia Arab.

Dakwah Hasan Al-Banna dengan berbagai kekaguman atas prestasi yang telah dibuatnya, kesungguhan, ketekunan, keikhlasan telah mempengaruhi pola pikir beberapa kalangan muslim termasuk di Indonesia. Paling tidak walau tidak lahir cabang Ikhwanul Muslimin di Indonesia, tapi beberapa pikirannya itu tuurut memberikan pengaruh terhadap pola pemahaman keagamaan sebagian masyarakat di Indonesia.

Hasil penelitian ini fokus pada pesan, penelitian yang utuh sebaiknya dilakukan bukan saja isi pesan tapi bagaimana pola, metode, strategi gerakan dakwah Hasan Al-Banna sehingga tampak kejelasan paradigma pemikiran dan gerakan dakwahnya. Dakwah tanpa pesan memang tidak memiliki makna apa-apa, 
tapi dakwah juga tidak semata-mata pesan, melainkan kapan harus disampaikan, kepada siapa saja pesan disampaikan, siapa yang menyampaikannya, melalui media apa dan seterusnya akan dapat menyempurnakan kegiatan dakwah.

\section{Daftar Pustaka}

Al-Banna, Hasan. Majmuatu Rasail. Mesir: Al-Bashair Li al-Buhuts wa ad-Dirosat, 2012

asy-Syurbaji, Ahmad Hasan, al-Imam asy-Syaahid Hasan al-Banna Mujaddid al-Qarn ar-Rabi' Asyr al-Hijry, cet. ke-1. Iskandariyah: Daar ad-Dakwah: 1998

Eriyanto, Analisis Wacana Pengantar Analisis Teks Media. Yogyakarta: LKIS, 2008.

Hadisaputra, Samian. "Kontekstualisasi Pemikiran Dakwah Hasan Al-Banna" dalam Jurnal Aqlania, (Banten: UIN Sultan Maulana Hasanudin) No. 1/Juni 2017

Hemlan Elhany, Dakwah Islam Di Eras Globalisasi Perspekstif Bimbingan Penyluhan Islam, Jurnal Bimbingan Penyuluhan Islam Vol.1 No.2 Juli-Desember 2019

Iin Masniyah, Tujuan Pendidikan Islam dan Gerakan Ikhwanul Muslimin Munurut Hasan Al-Banna dalam Jurnal Istoria: Jurnal Pendidikan dan Sejarah (Yogyakarta: Universitas Negeri Yogyakarta, Fakultas Ilmu Sosial, Prodi Pendidikan Sejarah) No. 2/September 2019

Kholik, Abdul. Pemikiran Pendidikan Islam Kajian Tokoh Klasik dan Kontemporer. Semarang: UIN Walisongo dengan Pustaka Pelajar, 2009

Mohammad, Herry, dkk, Tokoh-tokoh Islam yang Berpengaruh Abad 20. Jakarta: GemaInsani Perss. 2006

Mursi, Muhammad Said, Tokoh-tokoh Besar Isalam Sepanjang Sejarah, Jakarta: Pustaka Al-Kautsar. 2007

Ramayulis dan Nizar, S. Ensiklopedi Tokoh Pendidikan Islam. Jakarta: Quantum Teaching, 2005. 
Ridwan, Hubungan Islam dan Politik di Indonesia Perspektif Pemikiran Hasan Al-Banna dalam Jurnal Samudra Keadilan (Malang: Universitas Muhammadiyah Malang) No. 2/ Desember 2017

Rodiyah, Sejarah Perkembangan Ikhwanul Muslimin dan Kontribusinya dalam Dakwah Islam dalam Jurnal Ath-Thariq: Jurnal dakwah dan Komunikasi (Lampung: IAIN Metro) No. 1/Juni 2019

Rosmaladewi, Pemikiran Politik Hasaan Al-Banna dalam Jurnal Nuranii, (Palembang: Universitas Islam Negeri Raden Fatah) No. 2/Desember 2015.

Zaeni Hasan Al-Banna dan Strategi Perjuangannya dalam Jurnal AlAdyan, (Lampung: Universitas Islam Negeri Raden Intan) No. 2/Juli 2011.

Zainudin, Hasyim, dkk, Pendekatan Hasan Al-Banna dalam Pembangunan Insan Menyusuri Majmuatu Rasail. dalam Jurnal Hadhari, (Kualalumpur: Jabatan Dakwah dan Pembangunan Insan, Akademi Pengajian Islam) No. 7/Februari 2015 